\title{
Characterization of Mycoplasmas Isolated from Experimental Cats
}

\author{
Kaoru KOSHIMIZU, Masahiro ITO \\ and Teruo MAGARIBUCHI \\ Division of Animal Research, Faculty of Medicine, \\ University of Tokyo, Bunkyo-ku, Tokyo, 113, Japan
}

(Received for publication: March 19, 1979)

\begin{abstract}
Mycoplasmas were detected in $87(40.8 \%)$ of 213 specimens collected from 42 apparently healthy and 14 dead cats used for experimental purposes. These organisms were isolated from conjunctivae $(4 / 51: 7.8 \%)$, oral cavities $(46 / 52$ : $88.5 \%)$, nasal cavities $(30 / 55: 54.5 \%)$, prepuces $(2 / 21: 9.5 \%)$, vaginas $(3 / 30: 10.0 \%)$ and lungs $(2 / 4: 50.0 \%)$. A total of 167 strains cloned from these positive cultures was differentiated into 3 groups on the basis of their various biological characteristics as well as serological properties determined by the growth inhibition test. There were 26 strains identified as $M$. felis, 138 as $M$. gateae, and 3 as $M$. feliminutum. M. felis was only isolated from the conjunctivae, oral and nasal cavities, whereas $M$. gateae was found to be widely distributed in both the upper respiratory and urogenital tracts, but never isolated from the conjunctivae. $M$. feliminutum was only isolated from the oral cavities. This is the first isolation of these mycoplasma species from a feline origin in Japan.
\end{abstract}

実験用ネコから分離されたマイコプラズマの性状

舆水馨 ·伊藤正博 ・曲淵輝夫

東京大学医学部附属動物実験施設

ネコのマイコプラズマは, 1954年 Switzer [23]によ ってネコの曽炎から初めて分離されて以来今日まで, Mycoplasma felis [8], M. gateae [8], M. feliminutum [11], M. arginini [13, 28], Acholeplasma laidlawii $[26,28]$ ならびに Ureaplasma sp.（いわゆ るTーマイコプラズマ) $[10,24]$ が報告されている。こ れらのマイコプラズマは, 健康ネコ $[8,11,14,26]$ ある いは, 結膜炎・鼻炎など各種疾病䍜患ネコ $[1,3,4,8,9$, $17,19,21,22,25,27,28]$ の眼, 呼吸器および必尿生殖器 などから主として分離されてきた。しかし，ネコにおけ るこれら菌種の生態学的あるいは病原学的意義について は不明の点がきわめて多く，わが国に拈いても, Hara- sawa ら [10]によるウレアプラズマの分離報告がある のみで, マイコプラズマとネコの疾病との関係は明らか にされていない。

今回著者らは，実験用として使われる日本ネコからマ イコプラズマおよびウレアプラズマの分離をこころみた ところ，多くの菌株を分離したので，ここではマイコプ ラズマの分離状況ならびに分離株の生物学的および血清 学的性状について報告する。

\section{材料および方法}

被検動物：著者らの施設技よび某民間企業施設に夹験 
Table 1. Isolation of mycoplasmas from various sites of cats

\begin{tabular}{lccccrc}
\hline \multicolumn{1}{c}{ Site tested } & Healthy & $(\%)$ & Dead & $(\%)$ & Total & $(\%)$ \\
\hline Conjunctiva & $1 / 38^{*}$ & $(2.6)$ & $3 / 13$ & $(23.1)$ & $4 / 51$ & $(7.8)$ \\
Oral cavity & $38 / 41$ & $(92.7)$ & $8 / 11$ & $(72.7)$ & $46 / 52$ & $(88.5)$ \\
Nasal cavity & $23 / 42$ & $(54.8)$ & $7 / 13$ & $(53.8)$ & $30 / 55$ & $(54.5)$ \\
Prepuce & $2 / 17$ & $(11.8)$ & $0 / 4$ & & $2 / 21$ & $(9.5)$ \\
Vagina & $2 / 23$ & $(8.7)$ & $1 / 7$ & $(14.3)$ & $3 / 30$ & $(10.0)$ \\
Lung & ND** & & $2 / 4^{* * *}(50.0)$ & $2 / 4$ & $(50.0)$ \\
\hline
\end{tabular}

* : No. positive / No. examined

**: Not done

*** : Pneumonia

用動物として搬入された合計 56 匹の日本ネコ（Felis catus）を検査した。このうち，42匹（雄19匹，雌23匹） は外見的に健康であり, 残りの 14 匹（雄 6 匹，倠 8 匹） は，何等かの原因により死亡したものである。大部分は 親ネコであるが年龄は不詳である。

標涑菌株：生物学的ならびに血清学的性状の検査にお いて標準菌株として使用したマイコプラズマ菌株のうち, $M$. felis CO, M. gateae Mart, $M$. orale NCTC 10112, M. buccale NCTC 10136, M. salivarium NCTC 10113, $M$. fermentans NCTC 10117, $M$. hominis PG 21, M. canis PG 14, M. edwardii PG 24, M. pulmonis m 53, M. neurolyticum PG 28 お 上び $M$. arginini $\mathrm{G} 230$ は東京大学農学部尾形学教授 より分与をらけた。また $M$. feliminutum Ben は FAO/WHO Collaboratory Centre, University of Aarhus, Denmark の Dr. S. Rosendal から提供を らけた。

分離培地：分離培地としては，先に報告 [16]したよ 5に, PPLO-broth (Difco) 飞無菌馬血清を 20\%，自 家製の $25 \%$ （w/v）イーストエキストラクト（日本甜菜 糖）を $10 \%$ ，抗菌剤として 100,000 単位 $/ \mathrm{ml}$ のペリシリ ン $\mathrm{G}$ (明治製菓) を $1 \%$ 扰よび $2.5 \%$ 酢酸タリウム（和 光純薬）を $1 \%$,さらに指示薬として $0.4 \%$ フェノル レッドを $0.25 \%$ の割合に加えたものを基礎培地とし，こ れにグルコースを $0.5 \%$ の割合に添加した培地（pH7.8） およびアルギニンを $0.2 \%$ の割合に添加した培地（pH 7.0）をそれぞれ用いた。固型培地としては上記基礎培 地に Bacto-agar（Difco）を1.2\%の割合に加えた。

分離方法：動物は搬入後ただちに被検材料を操取し た。結膜, 口腔, 鼻腔, 包皮㧍よび胠からは滅菌綿棒に よりぬぐい取った粘液を, 肺は PPLO-broth (Difco)
で約10\%乳剤とし，その $3,000 \mathrm{rpm} 5$ 分遠沈上清の 0.1

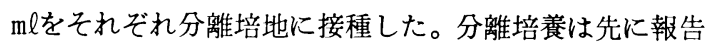
［16］したように，液体培地による增菌法と固型培地に よる直接法を併用した。

生物学的性状の検查: 分離菌株は Taylor-Robinson ら［31］の方法に準拠し, 単個コロニーより釣菌してク ローニングを行い，さらに抗菌剤無添加の基礎培地で 3 代継代し， L型菌でないことを確認してから実験に供し た。

血清要求性, グルコース分解性, アルギニン分解性, ウレアーゼ活性, テトラン゙リウム還元性扰よびフィルム ・スポット産生性など各種生物学的性状の検査は先に報 告［16］した方法にもとづいて行った。

血清学的性状の検査: 各菌株に対する家兔免度血清は, 先に報告 [15]した方法により, マイコプラズマ大量培 養菌の100倍濃縮抗原と Freund のコンプリート・アジ ュバント (IATRON) を混合乳剤とし，これをウサギ の皮下に, ついで生菌のみを静脈内に繰返し接種して作 製した。血清学的性状の検査は, Clyde [7] のディス ク発育阻止試験により行った。

\section{実験成縤}

\section{1. 分離成績}

マイコプラズマが健康ネコおよび死亡ネコの結膜,

腔, 鼻腔, 包皮あるいは腔より, また死亡ネコの肺より Table 1 に示すように分離された。口腔はもっとも分 離率が高く，鼻腔がこれに次いだ。これにくらべ結膜お 上び泌尿生殖器からの分離率は低かった。

2. 分離株の集落形態

初代分離株の固型培地上の集落形態は打おむ和 3 種類 
Table 2. Biological properties of mycoplarmas from feline origin

\begin{tabular}{|c|c|c|c|c|c|c|c|}
\hline & Strain & $\begin{array}{l}\text { Serum } \\
\text { requirement }\end{array}$ & $\begin{array}{l}\text { Glucose } \\
\text { break down }\end{array}$ & $\begin{array}{l}\text { Arginine } \\
\text { break down }\end{array}$ & $\begin{array}{l}\text { Urea } \\
\text { hydrolysis }\end{array}$ & $\begin{array}{l}\text { Tetra- } \\
\text { zolium } \\
\text { reduction }\end{array}$ & $\begin{array}{l}\text { Film \& spot } \\
\text { production }\end{array}$ \\
\hline \multirow{4}{*}{$\begin{array}{l}\text { Type } \\
\text { strain }\end{array}$} & M. felis CO & + & + & - & - & - & - \\
\hline & M. gateae Mart & + & - & + & - & - & - \\
\hline & M. feliminutum & + & - & - & - & - & - \\
\hline & M. arginini G 230 & + & - & + & - & - & - \\
\hline \multirow{3}{*}{$\begin{array}{l}\text { Isolated } \\
\text { strain }\end{array}$} & $\begin{array}{l}\text { Glucose } \\
\text { fermenting } \\
\qquad(26 \text { strains })\end{array}$ & + & + & - & - & - & -- \\
\hline & $\begin{array}{l}\text { Arginine } \\
\text { hydrolysing } \\
\qquad(138 \text { strains })\end{array}$ & + & - & + & - & - & - \\
\hline & $\begin{array}{l}\text { Miscellaneous } \\
\quad(3 \text { strains })\end{array}$ & + & - & - & - & - & - \\
\hline
\end{tabular}

が慧められた。その第 1 は大型で表面はやや顆粒状, 淡 褐色を呈し, 中心部に濃い“ニップル”があるもの (Fig. 2), 第 2 は表面が 粗雑で顆粒状ないしレース状の模様が 認められ中心部に明瞭な“ニップル”があるもの（Fig. 4)，第 3 は前 2 者に比較し，表面は緻密で中心部に明瞭 な“ニップル”が認められるもの（Fig. 6) などであっ た。これらの株は後述するよらに，それぞれ $M$. felis， M. gateae および $M$. feliminutum と同定された。 M. felis および M. gateae の集落形態は, Cole ら[8], Heyward 5 [11], Hill [12] あるいは Tan 5 [27] の記載にほぼ一致した。これらの分離株に比較し, 標準 株はいずれも緻密な表面構造を示し，この傾向はとくに M. gateae Mart 株 (Fig. 3) において著しかった。 3. 分離株の生物学的性状

分離株から同一分離培地に発育した異なる集落形態の 株を選んで, 合計 167 株をクローニングし, 各種生物学 的性状を検査し標準株と比較した。Table 2 に示すよ らに, 分離株はすべて発育のため血清を要求し, 尿素を 分解せず，テトラゾリウム塩を還元せず，フィルム・ス ポットを産生しなかった。それらのらち26株はグルコー スを分解し M. felis CO 株と同じ性状を示し，138株は アルギニンを分解し $M$. gateae Mart 株もしくは $M$. arginini G 230 株と同じ性状を示した。残りの 3 株は グルコースもアルギニンも分解せず $M$. feliminutum Ben 株にその性状が一致した。

4. 分離株の血清学的性状

分離株のらちから生物学的性.状をもとにして選んだ 4
株（C 51nd 2，C 2，C 23-2 および C 1-1）とヒトおよ び各種動物由来の標準株を用いて，家兔免度血清による 交差発育阻止試験を行い, 各菌株間の血清学的性状を比 較検討した。その成績は Table 3 に示すように，C51 nd 2 は $M$. felis CO К, C 2 は M. gateae Mart に抗原性が一致した。また C 23-2は M. gateae Mart と, C 1-1 は $M$. feliminutum Ben と少なくとも共 通の抗原性があることが明らかにされた。しかしこれら のネコ由来株は, ヒト由来 $M$. orale, $M$. buccale, $M$. salivarium, $M$. fermentans, $M$. hominis ならびに 各種動物由来の M. canis, M. edwardii, M. pulmonis, $M$. neurolyticum および $M$. arginini の各菌種 とは全く抗原的共通性が垫められなかった。

5. ネコ由来株の同定

ネコから分離した 167 株に対し，分離株および標準株 の家兔免疫血清を用い発育阻止試験を行ったところ，26 株は抗 $M$. felis CO 血清および抗 C 51nd 2 血清によ り，138株は抗 M. gateae Mart 血清あるいは抗 C23 -2 血清のいずれかにより, 残りの 3 株は抗 C 1-1 血清 に上りそれぞれ発育阻止された。抗 M. arginini G 230 血清によっては，すべての分離株が発育阻止されなかっ た。先に検討した生物学的性状ならびにこれらの血清学 的性状にもとづき，Table 4 に示寸ように，菌種内に 若干の抗原性の差はあるが，ネコから分離された株は， 26 株が M. felis, 138 株が M. gateae, 残りの 3 株が M. feliminutum と同定された。 6. 各菌種の検索部位別分離状況 
Table 3. Serological comparison by growth inhibition test between feline mycoplasmas and those from other animals and man

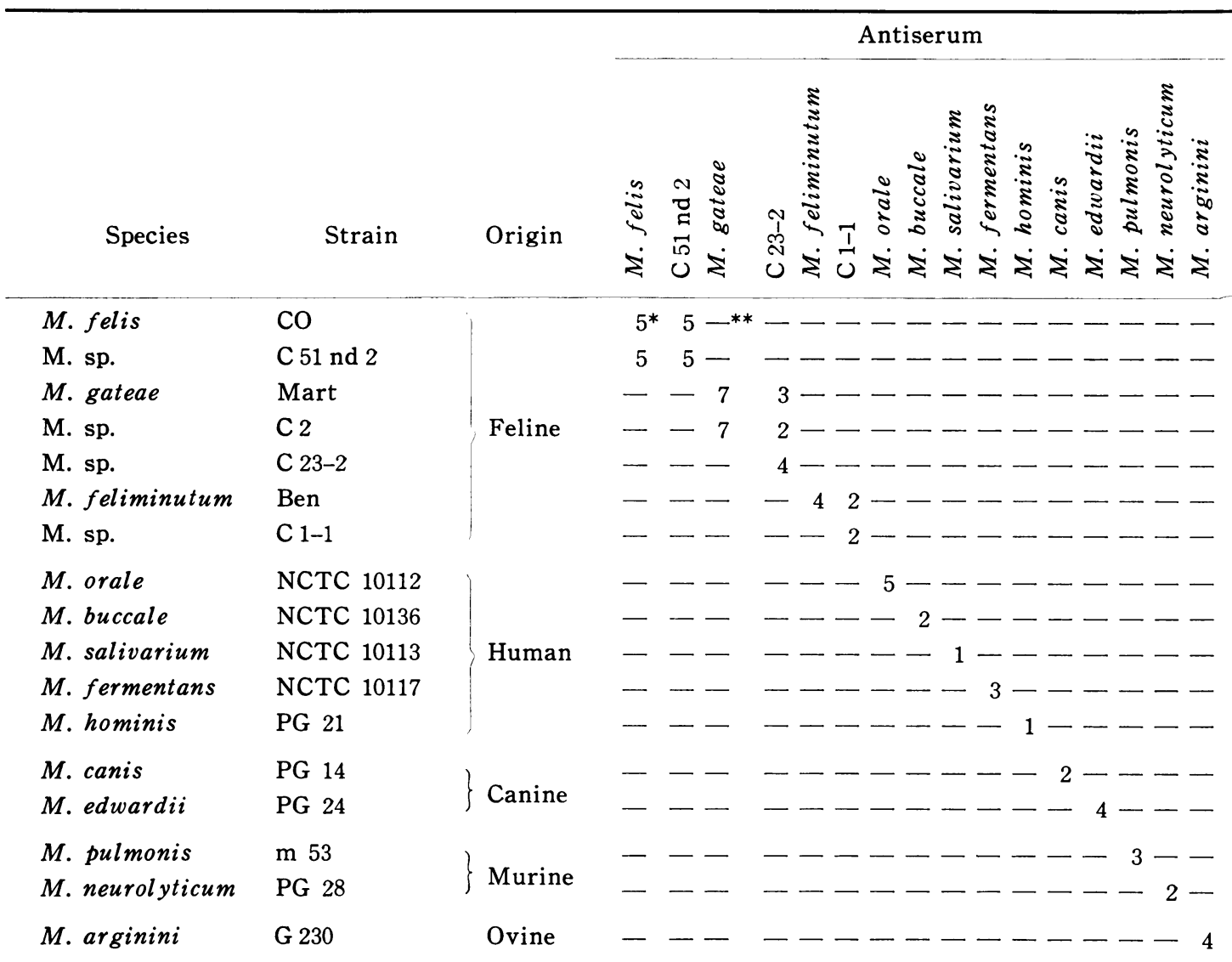

* : The width (mm) of a growth-inhibiting zone.

** : No growth inhibition.

今回分離された 3 菌種 167 株のネコにおける検索部位 別分離状況をみると，Table 5 に示すように $M$. felis は健康ネコおよび死亡ネコともに結膜，口腔および鼻腔 からのみ分離されたが，泌尿生殖器からは分離されなか った。一方, M. gateae は, 結膜からは分離されなか ったが, ネコの健康状態にかかわらず呼吸器, 泌尿生殖 器などに広く分布していることが判明した。 M. felim inutum は健康ネコの口腔からのみ分離された。

\section{考察}

今回の調査により，わが国の実験用ネコに高率にマイ コプラズマが棲息していることが初めて確認され，それ らはこれまでに報告 $[8,11]$ された 3 菌種すなわち， $M$. felis, M. gateae および M. feliminutum であるこ とが明らかにされた。

M. felis は結膜， 口腔および鼻腔からのみ分離され たが， M. gateae は結膜からは分離されず，呼吸器お よび泌录生殖器などに広く分布することが明らかにされ た。Heyward ら[11]は雄ネコおよび比ネコの生殖器よ りそれぞれ10\%，27\%の率で M. felis を分離している が, 今回の調査で本菌種が泌尿生殖器より分離されなか った理由は明らかではない。M. feliminutum は Heyward ら [11] によってネコの口㓐からのみわずか 1 株分離されたことが報告されているのみで，その後の研 究者によっても本菌種の分離報告例は見当らない。この マイコプラズマは人工培地に佂ける増殖力が他の菌種に くらべ弱く, かつ生物学的活性に乏しいため, 増殖力が 
Table 4. Differentiation and identification of mycoplasmas from cats

\begin{tabular}{|c|c|c|c|c|c|c|c|c|c|c|c|}
\hline \multirow[b]{2}{*}{$\begin{array}{l}\text { Species } \\
\text { identified }\end{array}$} & \multirow[b]{2}{*}{$\begin{array}{l}\text { No. of } \\
\text { strain } \\
\text { tested }\end{array}$} & \multicolumn{3}{|c|}{$\begin{array}{l}\text { Biological } \\
\text { properties }\end{array}$} & \multicolumn{7}{|c|}{$\begin{array}{l}\text { Growth inhibition } \\
\text { by antiserum }\end{array}$} \\
\hline & & $\begin{array}{l}0 \\
0 \\
0 \\
0 \\
\\
\end{array}$ & $\underset{\stackrel{\Xi}{\Xi}}{\stackrel{\Xi}{\Xi}}$ & $\stackrel{\mathscr{\Perp}}{\triangleright 口}$ & 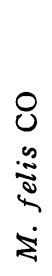 & $\begin{array}{c}v \\
0 \\
\tilde{D} \\
0\end{array}$ & 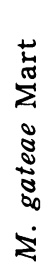 & ণ & 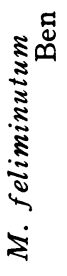 & $\frac{i}{u}$ & 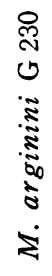 \\
\hline M. felis & 26 & + & - & - & + & + & - & - & - & - & 一 \\
\hline \multirow{2}{*}{ M. gateae } & $\int 128$ & - & + & - & - & - & + & + & - & - & - \\
\hline & 10 & - & + & - & - & - & - & + & - & - & - \\
\hline M. feliminutum & 3 & - & - & - & - & - & - & - & - & + & - \\
\hline Total & 167 & & & & & & & & & & \\
\hline
\end{tabular}

Table 5. Distribution of mycoplasma species in cats

\begin{tabular}{|c|c|c|c|c|c|}
\hline \multirow{2}{*}{ Condition } & \multirow{2}{*}{ Site } & \multirow{2}{*}{$\begin{array}{l}\text { No. of } \\
\text { strain }\end{array}$} & \multicolumn{3}{|c|}{ Mycoplasma species } \\
\hline & & & M. felis & M. gateae & M. feliminutum \\
\hline \multirow{5}{*}{$\begin{array}{l}\text { Healthy } \\
\text { (42 cats) }\end{array}$} & Conjunctiva & 5 & 5 & & \\
\hline & Oral cavity & 84 & 8 & 73 & 3 \\
\hline & Nasal cavity & 36 & 8 & 28 & \\
\hline & Prepuce & 3 & & 3 & \\
\hline & Vagina & 2 & & 2 & \\
\hline \multirow{7}{*}{$\begin{array}{l}\text { Dead } \\
\text { (14 cats) }\end{array}$} & Conjunctiva & 2 & 2 & & \\
\hline & Oral cavity & 20 & 1 & 19 & \\
\hline & Nasal cavity & 10 & 2 & 8 & \\
\hline & Prepuce & & & & \\
\hline & Vagina & 2 & & 2 & \\
\hline & Lung & 3 & & 3 & \\
\hline & Total & 167 & 26 & 138 & 3 \\
\hline
\end{tabular}

旺盛で生物学的活性にも富む $M$. felis や M. gateae の過增殖の陰にかくされてしまい，分離率の低下をもた らしたものと考兄れる。一方, Hill [13]および Tan \& Miles [26,28]によってネコからの分離が報告され ている M. arginini あるいは A. laidlawii は, 今回 の調査では分離されなかった。Hill［13］はネコ以外の 多くのネコ属の動物から高頻度に M. arginini を分離
しており，このことは本菌種の生態分布を知るらえで興 味ある知見である。他の動物種に㧊けるマイコプラズマ の棲息状況からして，ネコにおいてもさらに未確認の種 あるいは血清型が存在する可能性は大きい。その検出の ためには, M. felis および M. gateae のような增殖 力の旺盛なマイコプラズマを抑制し, 增殖力の弱い菌種 を選択的に分離できる培地の改良が今後の研究課題であ 
ろう。

ネコのマイコプラズマと疾病との関係は現段階で不明 の点がきわめて多い。Cello［4]はネコの結膜炎より初 めてマイコプラズマを分離した。Cole ら［8］はネコの 結膜炎から分離した $M$. felis を健康ネコの眼に接種し たところ， 2 匹のらち 1 匹に高度の粘液性の流涙を伴ら 結膜炎の発症を認めた。Campbell ら [3]は, 流淚, 眼 䀫痙絲および高度の結膜充血を伴った 9 匹のネコの眼か ら M. felis を分離した。このネコの結膜炎にオキシ テトラサイクリンが卓効を示したことから，本病に $M$. felis が重要な因子として関与していることを示唆した。 Tan \& Miles $[27,28]$ は, 臨床的に病気ネコあるいは 死亡ネコの結膜, 咽喉頭および鼻腔より高率に M. felis を分離すると共に，これらのネコに执いて，M. felis に対する血中代謝阻止抗体価および補体結合抗体価が有 意に高いことから，ネコの結膜炎あるいは呼吸器疾患に 本菌が関与していることを示唆した。Tan [29]はさら にM. felis を健康ネコの眼に実験的に接種して結膜炎 を怙こさせると共に，血中抗体価が上昇することを認め， ネコの結膜炎の起因菌として M. felis の重要性を指摘 した。

一方， Blackmore ら [1] は，英国における実験用 ネコの繁殖コロニーの調査において，16匹のネコの眼か ら M. felis のみを分離したが，このらち結膜炎を患っ ていたのは 8 匹だけであり, さらに別の 24 匹のコの結 膜炎からはマイコプラズマを分離することができなかっ た。その後さらに Blackmore ら [2]は，人工培養の M. felis を SPF ネコの結膜に接種したところ, 本菌 は定着したが結膜炎をおこすには至らなかった。このよ らに同一菌種でありながら，研究者によって異なる成績 が得られているので, マイコプラズマとネコの疾病との 関係には, 菌株の病原性, ネコの感受性あるいは他の微 生物の共存などマイコプラズマ病特有の複雑な要因が絡 んでいることが予想される。

ネコを宿主とするもらひとつのマイコプラズマである M. gateae については, Tan \& Miles [27]によると, 本菌種は病気ネコ, 死亡ネコあるいは健康ネコのいずれ からも同様に高率に分離され，しかもこのマイコプラズ マに対する血中抗体価はほとんど認められないことから， 本菌種はネコの呼吸気道における正常菌叢のひとつとさ れている。さらに Tan ら [30]によってネコの口腔か ら高率に分離された M. arginini は, 実験感染によっ て結膜に定着はするが症状は認められなかったことが報 告されている。
今回著者らが調査したネコは一部死亡したネコも含ま れるが健康なものが大部分を占め, そのマイコプラズマ 分離率はネコに拈ける本菌属のおおよその正常菌叢を示 しているものと考えられる。しかし, 健康ネコと死亡ネ コとの間のマイコプラズマの分離率 (Table 1) をみる と,たとえば結膜では健康ネコ $2.6 \%$, 死亡ネコ $23.1 \%$ で両者は有意に差があると思われるが, 今回はネコの死 亡原因, あるいは疾病の有無・種類とマイコプラズマ分 離の関係については検討しなかったので, 本菌属とネコ の疾病との因果関係については何等言及することはでき ない。しかしおそらく，マイコプラズマの一般的性質で ある病原性の弱さからして, これらの菌種が一次的であ るにせよ, 二次的であるにせよ, 単独で関与しているよ り, むしろ他の細菌あるいはウイルスとの共存により病 気を重篤なものにしていることが想像されらる $[4 \sim 6$, $18,20,21]$ 。

\section{要 約}

実験用動物として使われた外見的に健康なネコ 42 匹お よび死亡ネコ14匹から採材した 213 材料のうち，87(40.8 \%) 材料からマイコプラズマが検出された。これらのマ イコプラズマは結膜 $(4 / 51: 7.8 \%)$, 口腔 $(46 / 52: 88$. $5 \%)$, 鼻腔 (30/55: $54.5 \%)$, 包皮 $(2 / 21: 9.5 \%)$, 腔 (3/30: 10.0\%) および肺（2/4:50.0\%）から分離され た。分離株からクローニングされた 167 株は, 各種生物 学的性状ならびに発育阻止試験による血清学的性状にも とづいて 3 群にわかれた。すなわち，26株は $M y c o p l$. asma felis, 138 株は M. gateae, 残りの 3 株は $M$. feliminutum と同定された。M. felis は結膜, 口腔 および鼻腔からのみ分離されたが， M. gateae は結膜 からは分離されず，上部父道および泌尿生殖器などに広 く分布していることが明らかにされた。M. feliminut. um は口腔からのみ分離された。これらのマイコプラズ マ菌種の分離はわが国では最初である。

マイコプラズマ標準菌株の分与を賜った東京大学農学部尾形教 授ならびに材料採取に御援助を睗った三共株式会社中央研究所の 北野訓敏博士に深謝子る。本研究の一部は文部省科学研究費がん 特別研究費 (No. 301086) によった。 


\section{文献}

[1] Blackmore, D. K., Hill, A., and Jackson, O. F. (1971). The incidence of mycoplasma in pet and colony maintained cats. J. Small Anim. Pract., 12, 207-216.

[2] Blackmore, D. K., and Hill, A. (1973). The experimental transmission of various mycoplasmas of feline origin to domestic cats (Felis catus). J. Small Anim. Pract., 14, 7-13.

[ 3 ] Campbell, L. H., Snyder, S. B., Reed, C., and Fox, J. G. (1973). Mycoplasma felis-associated conjunctivitis in cats. J. Am. Vet. Med. Ass., 163, 991-995.

[4] Cello, R. M.(1975). Association of pleuropneumonialike organisms with conjunctivitis of cats. Am. J. Ophth., 43, 296-297.

[5] Cello, R. M. (1967). Ocular infections in animals with PLT (Bedsonia) group agents. Am. J. Ophth., 63, 1270-1273.

[6] Cello, R. M. (1971). Clues to differential diagnosis of feline respiratory infections. J. Am. Vet. Med. Ass., 158, 968-973.

[7] Clyde, W. A., Jr. (1964). Mycoplasma species identification based upon growth inhibition by specific antisera. J. Immunol., 92, 958-965.

[8] Cole, B. C., Golightly, L., and Ward, J. R. (1967). Characterization of mycoplasma strains from cats. J. Bact., 94, 1451-1458.

[9] Colegrave, A. T., lngham, B., and Inglis, J. M. (1964). Chronic rhinitis in cats. Vet. Rec., 76, 67-68.

[10] Harasawa, R., Yamamoto, K., and Ogata, M. (1977). Isolation of $\mathrm{T}$-mycoplasmas from cats in Japan. Microbiol. Immunol., 21, 179-181.

[11] Heyward, J. T., Sabry, M. Z., and Dowdle, W. R. (1969). Characterization of mycoplasma species of feline origin. Am. J. Vet. Res., 30, 615-622.

[12] Hill, A. (1971). Further studies on the morphology and isolation of feline mycoplasmas. J. Small Anim. Pract., 12, 219-223.

[13] Hill, A. (1975). Comparison of mycoplasmas isolated from captive wild felines. Res. Vet. Sci., 18, 139143.

[14] Jones, R. F., and Sabin, M. (1970). The isolation of mycoplasmas from clinically normal cats. Aust. Vet. J., 46, 343.

[15] Koshimizu, K., and Ohata, M. (1974). Characterization and differentiation of mycoplasmas of canine origin. Jap. J. Vet. Sci., 36, 391-406.

[16] 舆水 馨・曲淵輝夫・山本孝史・尾形 学 (1975). 輸入 サル類から分離されたマイコプラズマの性状. 実験動物,
24, 95-101.

[17] Lapras, M., and Papageorgiou, C. (1970). Isolement, identification et rôle des mycoplasmes dans les maladies respiratoires du chat. Revue Path. Comp. Med. Exp., 70, 239-245.

[18] Povey, P. C., and Wardley, R. C. (1973). Mycoplasma species in a cat colony. Vet. Rec., 92, 27-28.

[19] Schneck, G. (1970). Uber das Vorkommen von Mycoplasma species beim Virusschnupfen der Katze. Wien. Tierärztl. Mschr., 57, 105.

[20] Schneck, G. W. (1972). Mycoplasma species in association with feline viruses. Vet. Rec., 91, 594595.

[21] Schneck, G. (1973). Mycoplasma in a cat colony. Vet. Med. Small Anim. Clin., 68, 381-382.

[22] Spradbrow, P. B., Marley, J., Portas, B., and Burgess, G. (1970). The isolation of mycoplasmas from cats with respiratory disease. Aus. Vet. J., 46, 109110 .

[23] Switzer, W. P. (1967). The Genus Mycoplasma. In Veterinary Bacteriology and Virology. 7 th ed. Merchant, I. A., and Packer, R. A. editors, Iowa State University Press, Ames, Iowa, 531-548.

[24] Tan, R. J. S., and Markhm, J. G. (1971). Feline T-strain mycoplasmas. Jap. J. Exp. Med., 41, 247248.

[25] Tan, R. J. S., and Markham, J. (1971). Isolation of mycoplasma from cats with conjunctivitis. New Zeal. Vet. J., 19, 28.

[26] Tan, R. J. S., and Miles, J. A. R. (1972). Mycoplasma isolations from clinically normal cats. $\mathrm{Br}$. Vet. J., 128, 87-90.

[27] Tan, R. J. S., and Miles, J. A. R. (1973). Characterization of mycoplasmas isolated from cats with conjunctivitis. New Zeal. Vet. J., 21, 27-32.

[28] Tan, R. J. S., and Miles, J. A. R. (1974). Incidence and significance of mycoplasmas in sick cats. Res. Vet. Sci., 16, 27-34.

[29] Tan, R. J. S. (1974). Susceptibility of kittens to Mycoplasma felis infection. Jap. J. Exp. Med., 44, 235-240.

[30] Tan, R. J. S., Lim, E, W., and Ishak, B. (1977). Significance and pathogenic role of Mycoplasma arginini in cat disease. Canad. J. Comp. Med., 41, 349-354.

[31] Taylor-Robinson, D., Canchola, J., Fox, H., and Chanock, R. M. (1964). A newly identified oral mycoplasma (M. orale) and its relationship to other human mycoplasmas. Am. J. Hyg., 80, 135-148. 

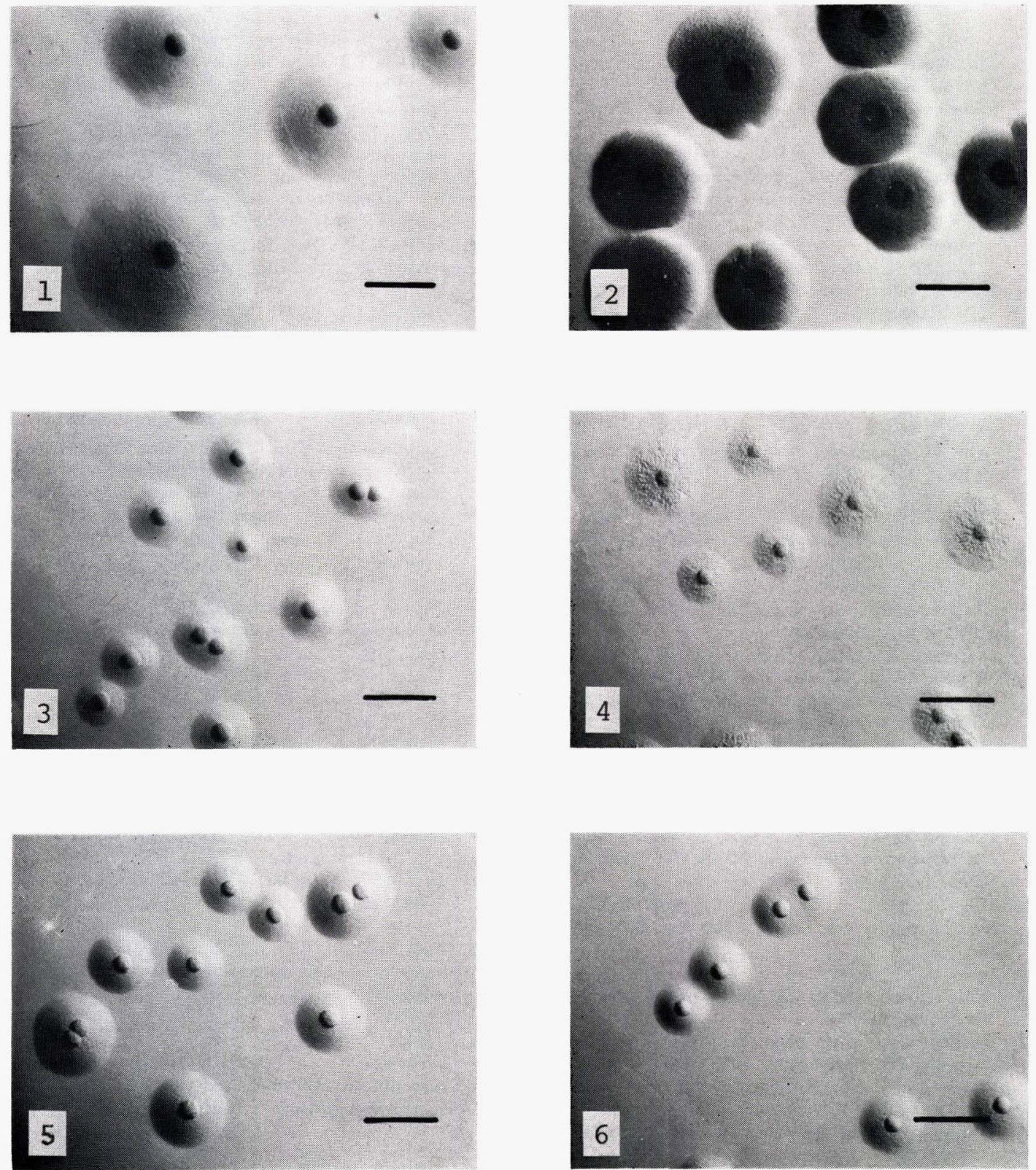

\section{Explanation of Figures}

Fig. $1 M$. felis $\mathrm{CO}$

Fig. 3 M. gateae Mart

Fig. 5 M. feliminutum Ben

Bars indicate $0.2 \mathrm{~mm}$.
Fig. $2 M$. felis $\mathrm{C} 51$ nd 2

Fig. 4 M. gateae C 23-2

Fig. 6 M. feliminutum $\mathrm{C}_{1-1}$ 